\title{
PENERAPAN MODEL PEMBELAJARAN QUANTUM TEACHING UNTUK MENINGKATKAN MOTIVASI BELAJAR MATEMATIKA SISWA KELAS V SDN 009 BANGKINANG
}

\author{
Putri Hana Pebriana \\ Universitas Pahawan Tuanku Tambusai \\ Jl. Tuanku Tambusai No 23 Bangkinang \\ putripebriana99@gmail.com
}

\begin{abstract}
Abstact
The background of the problem in this research is the students do not understand the material given by the teacher. This is due to the learning of mathematics in the classroom by means of lecture methods with poor student involvement. Motivation to learn mathematics of students is still relatively low resulting in low learning results as well. Students are less enthusiastic, less active in expressing their opinions, less varied learning atmosphere. For that we need to improve learning with learning model Quantum Teaching. This model not only offers learning materials but how to create a good emotional connection in and when learning but also makes students interested and interested in math lessons. This form of research is a classroom study (PTK). This study aims to improve the motivation to learn mathematics of grade V students of State Elementary School 009 Bangkinang on widescreen flat matter. The results of this study indicate that in the first cycle repeat the student's average score increased by 9.8 points from the base score to 73.8. In the second cycle increased by 8.4 points from cycle I to 76.95. Qualitative data in the form of motivation test on the first cycle increased by 18.04 points from the basic score to 54.68 In cycle II increased 21.08 points from cycle I to 75.76 can be interpreted that the application of learning models Quantum Teaching can improve students' math motivation V SD Negeri 009 Bangkinang.
\end{abstract}

Keywords: Learning Model, Quantum Teaching, Learning Motivation

\begin{abstract}
Abstrak
Latar belakang masalah dalam penelitian ini adalah siswa kurang memahami materi yang diberikan guru. Ini disebabkan pembelajaran matematika di dalam kelas dilakukan dengan metode ceramah dengan keterlibatan siswa yang kurang. Motivasi belajar matematika siswa masih tergolong rendah sehingga mengakibatkan hasil belajar yang rendah pula. Siswa kurang bersemangat, kurang aktif dalam mengungkapkan pendapatnya, suasana pembelajaran yang kurang bervariasi. Untuk itu perlu dilakukan perbaikan pembelajaran dengan model pembelajaran Quantum Teaching. Model ini tidak hanya menawarkan materi pembelajaran tetapi bagaimana menciptakan hubungan emosional yang baik dalam dan ketika belajar tetapi juga membuat siswa menjadi tertarik dan berminat pada pelajaran matematika. Bentuk penelitianini adalah Penelitian Tindaka kelas (PTK). Penelitian ini bertujuan untuk meningkatkan motivasi belajar matematika siswa kelas V SD Negeri 009 Bangkinangpada materi luas bangun datar. Hasil penelitian ini menunjukkan bahwa pada ulangan siklus I nilai rerata siswa meningkat sebesar 9,8 poin dari skor dasar menjadi 73,8. Pada siklus II meningkat sebesar 8,4 poin dari siklus I menjadi 76,95. Data kualitatif berupa tes motivasi pada siklus I meningkat sebesar 18,04 poin dari skor dasar menjadi 54,68 Pada siklus II meningkat 21,08 poin dari siklus I menjadi 75,76 dapat diartikan bahwa penerapan model pembelajaran Quantum Teaching dapat meningkatkan motivasi matematika siswa kelas V SD Negeri 009 Bangkinang.
\end{abstract}

Kata Kunci: Model Pembelajaran, Quantum Teaching, Motivasi Belajar

Menurut James dan James (Suherman, 1999:120) matematika adalah ilmu tentang logika mengenai bentuk, susunan, besaran dan konsep-konsep berhubungan lainnya dengan jumlah yang banyak yang terbagi dalam tiga bidang, yaitu aljabar, analisis dan geometri.Menurut KTSP (2006: 158) tujuan pendidikan matematika yaitu agar peserta didik memiliki kemampuan yakni:Memahami konsep matematika, menjelaskan keterkaitan antar konsep dan mengaplikasikan konsep atau logaritma secara luas, akurat, efisien dan tepat dalam pemecahan masalah.Menggunakan penalaran pada pola sifat, melakukan manipulasi matematika, dalam membuat generalisasi, menyusun bukti atau 
menjelaskan gagasan dan menyatakan matematika.Memecahkan masalah meliputi kemampuan memahami masalah, merancang model matematika, menyelesaikan model dan menafsirkan solusi yang diperoleh.Mengkomunikasikan gagasan dan simbol, tabel, atau media untuk memperjelas keadaan atau masalah.Memiliki sikap menghargai kegunaan matematika dalam kehidupan, yaitu memiliki rasa ingin tahu, perhatian, dan minat dalam pemecahan masalah.

Berdasarkan wawancara dan hasil observasi peneliti di kelas V di SDN 009 Bangkinang pada umumnya pembelajaran matematika di dalam kelas dilakukan dengan metode ceramah (konvensional) dengan keterlibatan siswa yang minim. Motivasi belajar matematika siswa masih tergolong rendah sehingga mengakibatkan hasil belajar yang rendah pula. Hasil ini dapat dilihat dari banyaknya siswa yang belum mencapai Kriteria Ketuntasan Minimal (KKM) yang ditetapkan sekolah yaitu 69. Dari jumlah siswa sebanyak 25 siswa hanya 12 siswa yang mencapai KKM pada materi sifat-sifat bangun datar, sedangkan 13 siswa yang lainnya belum mencapai KKM. 12 siswa dari 25 siswa yang mencapai KKM hanya $48 \%$ yang dikatakan tuntas, sedangkan ketuntasan klasikal adalah $85 \%$ dari seluruh siswa. Hal ini disebabkan karena:

1. Matematika adalah pelajaran yang sulit dan membosankan karena berhubungan dengan rumus-rumus sehingga siswa merasa jenuh dan mengganggu teman sebangkunya.

2. Siswa kurang bersemangat dalam mengikuti proses pembelajaran karena letak sekolah yang terletak di lingkungan pasar yang menimbulkan kebisingan.

3. Di waktu pembelajaran berlangsung hanya sebagian siswa saja yang memiliki rasa ingin tahu, tidak mau untuk bertanya atau menjawab pertanyaan, serta kurang mengungkapkan ide-ide yang ada pada dirinya masing-masing.

4. Suasana pembelajaran cenderung kurang bervariasi sehingga siswa menjadi pasif karena guru tidak menggunakan media yang menarik bagi siswa.

5. Kurangnya perhatian dari orang tua kepada siswa karena mayoritas pekerjaan orang tua adalah sebagai pedagang.

\section{METODE}

Bentuk penelitian ini adalah penelitian tindakan kelas yang dilakukan secara kolaborasi. Dalam penelitian kolaboratif, pihak yang melakukan tindakan adalah guru itu sendiri, sedangkan yang diminta melakukan pengamatan terhadap berlangsungnya proses tindakan adalah peneliti, bukan guru yang sedang melakukan tindakan (Arikunto, 2009: 17). Kolaborasi juga dapat dilakukan oleh dua orang guru, yang dengan cara bergantian mengamati. Ketika sedang mengajar, dia adalah seorang guru; ketika sedang mengamati, dia adalah seorang peneliti. Mulyasa (2010: 11) menyatakan bahwa penelitian tindakan kelas merupakan suatu upaya untuk mencermati kegiatan belajar sekolompok peserta didik dengan memberikan peserta didik dengan sebuah tindakan (treatment) yang sengaja dimunculkan. 
Penelitian tindakan kelas adalah suatu pencermatan terhadap kegiatan belajar berupa sebuah tindakan, yang sengaja dimunculkan dan terjadi dalam sebuah kelas secara bersama. Tindakan tersebut diberian oleh guru atau dengan arahan dari guru yang dilakukan oleh siswa, dengan tujuan untuk memperbaiki dan meningkatkan kualitas pembelajaran di kelas secara lebih profesional. Berdasarkan karakteristik PTK, maka kolaborasi ( kerjasama) merupakan hal yang sangat penting dalam PTK. Arikunto (2009: 63) menerangkan bahwa " kerjasama antara praktisi dan peneliti dalam PTK sangat penting karena melalui bekerjasama mereka dapat secara bersama menggali dan mengkaji permasalahan nyata yang dihadapi guru dan siswa di sekolah”. Dalam penelitian ini tindakan akan dilakukan dalam dua siklus yang dilakukan secara sistematis. Siklus pertama dilaksanakan $4 \mathrm{x}$ pertemuan dengan perincian $3 \mathrm{x}$ pertemuan menyajikan materi dan 1x pertemuan dengan tes (ulangan siklus I) dan siklus kedua dilaksanakan $4 \mathrm{x}$ pertemuan dengan rincian $3 \mathrm{x}$ pertemuan menyajikan materi dan $1 \mathrm{x}$ pertemuan dengan tes (ulangan siklus II). Tiap-tiap siklus terdiri dari empat tahap meliputi: perencanaan, pelaksanaan, pengamatan dan refleksi. Adapun desain Penelitian Tindakan kelas mengikuti desain model spiral dan dapat digambarkan seperti di bawah ini:

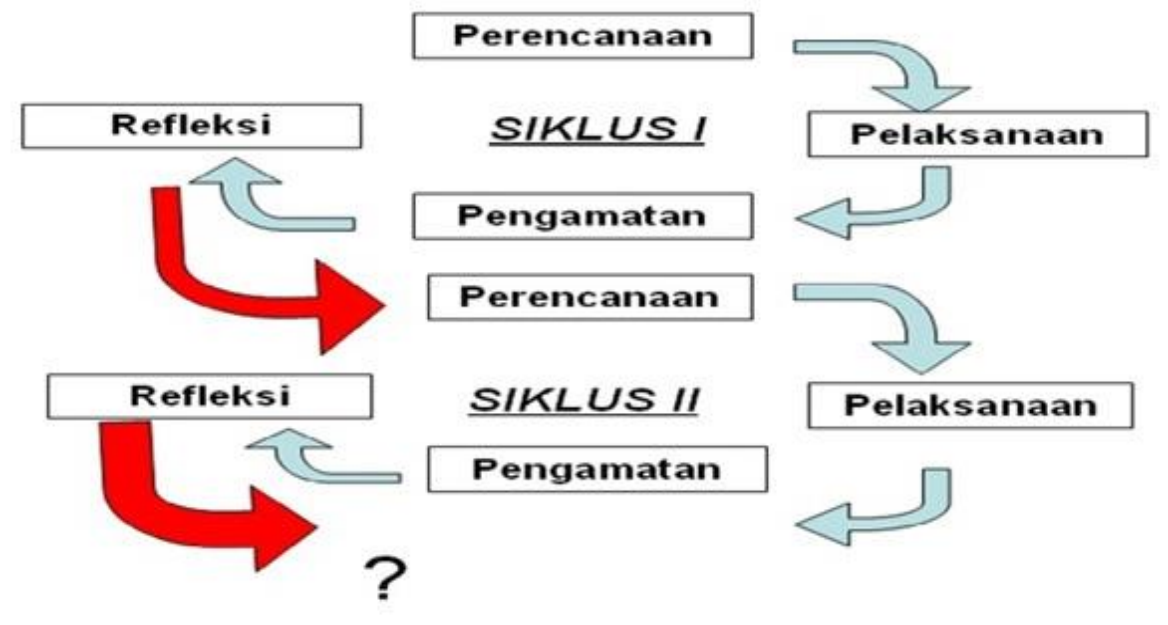

\section{HASIL PENELITIAN DAN PEMBAHASAN}

Hasil tindakan yang dianalisis yaitu aktivitas guru dan siswa selama proses pembelajaran dan tercapainya KKM hasil belajar matematika siswa untuk setiap dan seluruh Indikator.

\section{Aktivitas Guru}

Pada pertemuan pertama aktivitas guru belum sesuai dengan rencana. Namun, secara umum sudah dikategorikan baik. Peneliti masih belum bisa menguasai kelas dengan baik, dalam menjelaskan petunjuk pengerjaan LKS belum terlalu jelas sehingga siswa terlihat bingung saat mengerjakan LKS, peneliti tidak menjelaskan tata cara berkelompok sehingga dalam membentuk kelompok kelas menjadi ribut. Saat membimbing siswa dalam kelompok peneliti terlihat kurang sabar dan tidak mengecek kerjasama anggota kelompok serta peneliti masih belum bisa mengefisienkan waktu selama jam pelajaran berlangsung. 
Pada pertemuan kedua aktivitas guru mulai ada peningkatan dibandingkan dengan pertemuan pertama, peneliti masih belum bisa menguasai kelas dengan baik dan memotivasi siswa, masih ada siswa yang berbicara dengan temannya dan berjalan-jalan, peneliti masih kurang jelasdalam membimbing siswa merumuskan hipotesis dan mengerjakan LKS, tetapi dalam pertemuan kedua ini peneliti sudah menjelaskan tata cara berkelompok yang baik. Namun secara umum sudah dikategorikan baik.

Pada pertemuan ketiga ini aktivitas guru dikategorikan baik . Peneliti mulai bisa menguasai kelas dengan baik dan memotivasi siswa serta sabar dalam membimbing siswa dalam merumuskan hipotesis dan menjelaskan petunjuk pengerjaan LKS.

Pada pertemuan keenam aktivitas guru dikategorikan sangat baik karena telah sesuai dengan yang direncanakan. Ini terlihat dari seluruh aspek aktivitas peneliti yang hampir sempurna. Peneliti telah menguasai kelas dengan baik, peneliti telah dapat memicu dan memelihara ketertiban siswa saat apersepsi dan mengorganisasikan siswa dalam kelompok. Peneliti telah membimbing siswa dalam merumuskan hipotesis dan menjelaskan petunjuk pengerjaan LKS dengan baik dan sabar, peneliti juga telah menjelaskan tata cara berkelompok yang baik dan peneliti telah dapat menyesuaikan waktu pembelajaran yang efisien sesuai direncanakan.

Pada pertemuan ketujuh aktivitas guru juga dikategorikan sangat baik sesuai dengan langkah-langkah yang direncanakan. Pada pertemuan ini secara keseluruhan peneliti telah melaksanakan langkahlangkah pembelajaran sesuai dengan yang diharapkan. Peneliti juga telah dapat menyesuaikan waktu dengan jam pelajaran yang disediakan.

Pada pertemuan kedelapan aktivitas guru dikategorikan sangat baik. Pada pertemuan kedelapan ini proses pembelajaran telah sesuai dengan yang direncanakan dan berjalan dengan baik. Secara keseluruhan peneliti sudah menguasai kelas dan memotivasi siswa dengan baik.

Dari tabel pengamatan yang dilakukan dapat disimpulkan bahwa penerapan model pembelajaran Quantum Teaching telah sesuai dengan yang diharapkan dan dapat meningkatkan hasil belajar matematika siswa. Dari keseluruhan pertemuan aktivitas peneliti selama proses pembelajaran terdapat peningkatan pemahaman siswa terhadap tahap-tahap pembelajaran Quantum Teaching.

\section{Tabel 1}

Analisis Lembar Pengamatan Penerapan Model Pembelajaran Quantum Teaching Aktivitas Guru Siklus I dan II Selama Proses Pembelajaran

\begin{tabular}{|c|c|c|c|c|c|c|c|c|}
\hline \multirow{3}{*}{ No } & \multirow{3}{*}{\multicolumn{2}{|c|}{ Aktivitas Peneliti }} & \multicolumn{3}{|c|}{ Siklus I } & \multicolumn{3}{|c|}{ Siklus II } \\
\hline & & & \multicolumn{3}{|c|}{ Pertemuan } & \multicolumn{3}{|c|}{ Pertemuan } \\
\hline & & & I & II & III & VI & VII & VIII \\
\hline 1. & $\begin{array}{l}\text { Tumbuhkan } \\
\text { Menyampaikan }\end{array}$ & tujuan & 3 & 3 & 3 & 4 & 4 & 4 \\
\hline
\end{tabular}




\begin{tabular}{|c|c|c|c|c|c|c|c|}
\hline & pembelajaran & & & & & & \\
\hline 2. & Memotivasi siswa & 3 & 3 & 3 & 3 & 4 & 4 \\
\hline 3. & $\begin{array}{l}\text { ALAMI } \\
\text { Memberikan apersepsi }\end{array}$ & 3 & 2 & 2 & 3 & 3 & 4 \\
\hline 4. & $\begin{array}{l}\text { NAMAI } \\
\text { Menginformasikan } \\
\text { sebagian materi }\end{array}$ & 3 & 3 & 3 & 3 & 4 & 4 \\
\hline 5. & $\begin{array}{l}\text { Mengorganisasikan siswa } \\
\text { dalam kelompok }\end{array}$ & 3 & 3 & 3 & 4 & 4 & 4 \\
\hline 6. & $\begin{array}{lr}\text { Memberikan } & \text { bimbingan } \\
\text { melakukan } & \text { kegiatan } \\
\text { dalam LKS } & \\
\end{array}$ & 3 & 3 & 3 & 4 & 4 & 4 \\
\hline 7. & $\begin{array}{l}\text { DEMONSTRASI } \\
\text { Memberi bimbingan dalm } \\
\text { mendemonstrasikan hasil } \\
\text { diskusi kelompok }\end{array}$ & 2 & 3 & 3 & 4 & 4 & 4 \\
\hline 8. & 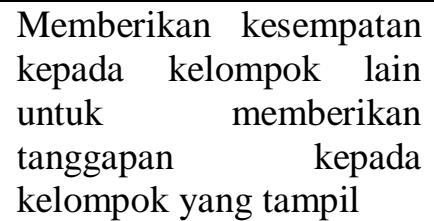 & 2 & 2 & 3 & 3 & 3 & 3 \\
\hline 9. & $\begin{array}{l}\text { ULANGI } \\
\text { Pengulangan materi yang } \\
\text { dipelajari }\end{array}$ & 3 & 3 & 3 & 4 & 4 & 4 \\
\hline 10. & $\begin{array}{l}\text { Memberikan latihan } \\
\text { lanjutan }\end{array}$ & 3 & 3 & 3 & 4 & 3 & 4 \\
\hline 11. & $\begin{array}{lr}\text { RAYAKAN } & \\
\text { Pemberian } & \text { respon } \\
\text { terhadap } & \text { kegiatan } \\
\text { perayaan yang } & \text { dilakukan } \\
\text { siswa } & \\
\end{array}$ & 2 & 3 & 3 & 3 & 4 & 4 \\
\hline \multicolumn{2}{|c|}{ JUMLAH SKOR } & 30 & 31 & 32 & 39 & 41 & 43 \\
\hline \multicolumn{2}{|c|}{ RATA-RATA (DIBAGI 11) } & 2,7 & 2,8 & 2,9 & 3,5 & 3,7 & 3,9 \\
\hline \multicolumn{2}{|c|}{ PERSENTASE $(\%)$} & $68,2 \%$ & $70,5 \%$ & $72,7 \%$ & $88,6 \%$ & $93,2 \%$ & $97,7 \%$ \\
\hline \multicolumn{2}{|c|}{ KATEGORI } & Baik & Baik & Baik & $\begin{array}{l}\text { Sangat } \\
\text { baik }\end{array}$ & $\begin{array}{l}\text { Sangat } \\
\text { baik }\end{array}$ & $\begin{array}{l}\text { Sangat } \\
\text { baik }\end{array}$ \\
\hline
\end{tabular}

Dari tabel 4.1 diatas terlihat bahwa secara umum aktivitas peneliti di siklus I dan II mengalami peningkatan. Dari jumlah skor, terlihat pada pertemuan pertama jumlah skor sebesar 30, pada pertemuan kedua jumlah skor sebesar 31, pada pertemuan ketiga sebesar 32, pada pertemuan keenam sebesar 39, pada pertemuan ketujuh sebesar 41 dan pada pertemuan kedelapan sebesar 43. Peningkatan jumlah skor tiap pertemuan adalah dari pertemuan pertama ke pertemuan kedua sebesar 1, dari pertemuan kedua ke pertemuan ketiga sebesar 1, dari pertemuan ketiga ke pertemuan keenam sebesar 7, dari pertemuan keenam ke pertemuan ketujuh sebesar 2, dan dari pertemuan ketujuh ke pertemuan kedelapan sebesar 2 .

Dari rata-rata, terlihat pada pertemuan pertama rata-rata sebesar 2,7, pada pertemuan kedua sebesar 2,8 , pada pertemuan ketiga sebesar 2,9, pada pertemuan keenam sebesar 3,5, pada pertemuan ketujuh 
sebesar 3,7 dan pada pertemuan kedelapan sebesar 3,9. Peningkatan rata-rata tiap pertemuan adalah dari pertemuan pertama ke pertemuan kedua sebesar 0,1, dari pertemuan kedua ke pertemuan ketiga sebesar 0,1, dari pertemuan ketiga ke pertemuan keenam sebesar 0,6, dari pertemuan keenam ke pertemuan ketujuh sebesar 0,2 dan dari pertemuan ketujuh ke pertemuan kedelapan sebesar 0,2.

Sedangkan dari persentase, terlihat pada pertemuan pertama persentase sebesar $68,2 \%$ dengan kategori baik, pada pertemuan kedua sebesar 70,5\% dengan kategori baik, pada pertemuan ketiga sebesar 72,7\% dengan kategori baik, pada pertemuan keenam sebesar 88,6\% dengan kategori sangat baik, pada pertemuan ketujuh sebesar 93,2\% dengan kategori sangat baik dan pada pertemuan kedelapan sebesar 97,7\% dengan kategori sangat baik. Peningkatan persentase tiap pertemuan adalah dari pertemuan pertama ke pertemuan kedua sebesar 2,3\%, dari pertemuan kedua ke pertemuan ketiga sebesar 2,2 \%, dari pertemuan ketiga ke pertemuan keenam sebesar 15,9\%, dari pertemuan keenam ke pertemuan ketujuh sebesar 4,6\% dan dari pertemuan ketujuh ke pertemuan kedelapan sebesar 4,5\%. Sedangkan peningkatan kategori tiap siklus adalah pada siklus I dikategorikan baik sedangkan pada siklus II dikategorikan sangat baik.

\section{Aktivitas Siswa}

Pada pertemuan pertama aktivitas siswa masih banyak kekurangan yang harus diperbaiki yaitu masih ada siswa yang masih melakukan kegiatan lain di saat peneliti menjelaskan materi dan menjelaskan petunjuk pengerjaan LKS seperti menggangu konsentrasi siswa lainnya dan lain-lain, sehingga siswa kurang memahami apa yang telah dijelaskan oleh peneliti. Saat pembentukan kelompok kelas menjadi ribut karena siswa belum mengetahui tata cara berkelompok yang benar, selain itu masih banyak siswa yang belum bisa mempergunakan media dengan benar, dan masih banyak kelompok yang belum membagi tugas, sehingga siswa yang pintar yang lebih mendominasi. Siswa masih belum terbiasa dengan model pembelajaran yang diberikan oleh peneliti, namun secara umum sudah dikategorikan baik.

Pada pertemuan kedua aktivitas siswa ini masih tergolong masih tergolong baik. Pada pertemuan kedua, masih ada siswa yang melakukan kegiatan lain. Siswa juga masih agak ribut dalam membentuk kelompok. Namun, siswa sudah bisa menerima teman sekelompoknya. Beberapa kelompok masih bingung pada saat penggunaan alat peraga untuk dapat menyelesaikan maslah di LKS. Namun, beberapa kelompok sudah terlihat bisa mengerjakan LKS tanpa bimbingan. Selain itu, masih ada siswa yang berjalan-jalan untuk melihat hasil kerja kelompok lain.

Pertemuan ketiga aktivitas siswa ini pun dikategorikan baik. Masih ada siswa yang melakukan aktivitas lain saat peneliti sedang menjelaskan. selain itu, ada beberapa kelompok yang telah bisa menggunakan media yang diberikan dengan benar, tetapi masih ada kelompok yang masih bingung 
mempergunakan media. Dalam membentuk kelompok, kelas tidak terlalu ribut seperti pada pertemuan-pertemuan sebelumnya. Namun, siswa mulai terbiasa dengan model pmbelajaran ini.

Pada pertemuan keenam aktivitas siswa tergolong sangat baik. Saat apersepsi siswa terlihat senang memulai pelajaran. Ini terlihat dari antusias siswa menjawab pertanyaan peneliti. Siswa telah berani mengeluarkan pendapat dan menjawab pertanyaan yang diberikan oleh peneliti, siswa lebih kelihatan aktif dibandingkan pertemuan sebelumnya. Hampir seluruh kelompok telah bisa menggunakan media dengan baik, siswa bersama kelompoknya telah bisa membagi tugas dengan baik, terlihat di setiap kelompok setiap anggotanya telah bekerja sama dalam mengerjakan LKS.

Pada pertemuan ketujuh aktivitas siswa sangat baik. Saat pembagian kelompok, setiap kelompok sudah mulai paham dalam menggunakan media kertas origami.. Sebagian besar siswa terlihat telah mulai dapat membagi tugas dan bekerja sama. Hanya beberapa siswa yang terlihat tidak aktif.

Pada pertemuan kedelapan aktivitas siswa dikategorikan sangat baik. Pada pertemuan kedelapan ini, proses pembelajaran berjalan dengan sangat baik dan sesuai dengan rencana peneliti. Secara keseluruhan, siswa sangat antusias mendengar motivasi yang diberikan peneliti. Selain itu saat penjelasan petunjuk pengerjaan LKS siswa juga sudah tidak melakukan kegiatan lain lagi. Seluruh siswa juga terlihat mahir menggunakan media dan seluruh kelompok telah membagi tugas dengan baik bersama anggotanya.

Berdasarkan tabel pengamatan, dapat disimpulkan bahwa penerapan model Pembelajaran Quantum Teaching telah sesuai dengan yang diharapkan dan dapat meningkatkan hasil belajar matematika siswa. Dari keseluruhan pertemuan aktivitas siswa selama proses pembelajaran terdapat peningkatan pemahaman siswa terhadap tahap - tahap pembelajaran Quantum Teaching.

Tabel 2

Analisis Lembar Pengamatan Penerapan Model Pembelajaran Quantum Teaching Aktivitas Siswa Siklus I dan II Selama Proses Pembelajaran

\begin{tabular}{|l|l|l|l|l|l|l|l|}
\hline \multirow{2}{*}{$\begin{array}{l}\text { No } \\
\cdot\end{array}$} & Aktivitas Siswa & \multicolumn{2}{|l|}{ Siklus I } & \multicolumn{2}{l|}{ Siklus II } \\
\cline { 2 - 8 } & \multicolumn{2}{|l|}{ Pertemuan } & & & \\
\cline { 2 - 8 } 1. & $\begin{array}{l}\text { TUMBUHKAN } \\
\text { Mendengarkan tujuan } \\
\text { pembelajaran yang } \\
\text { disampaikan oleh peneliti }\end{array}$ & 2 & 2 & 3 & 3 & 3 & 4 \\
\hline 2. & $\begin{array}{l}\text { Mendengarkan motivasi } \\
\text { yang disampaikan oleh } \\
\text { peneliti }\end{array}$ & 3 & 2 & 3 & 3 & 3 & 4 \\
\hline 3. & $\begin{array}{l}\text { ALAMI } \\
\text { Menanggapi apersepsi }\end{array}$ & 3 & 3 & 2 & 3 & 4 & 4 \\
\hline 4. & $\begin{array}{l}\text { NAMAI } \\
\text { Mendengarkan penjelasan } \\
\text { materi yang disampaikan }\end{array}$ & 3 & 3 & 3 & 3 & 4 & 4 \\
\hline
\end{tabular}




\begin{tabular}{|l|l|l|l|l|l|l|l|}
\hline & oleh peneliti & & & & & \\
\hline 5. & $\begin{array}{l}\text { Duduk dalam kelompok } \\
\text { yang telah ditentukan }\end{array}$ & 3 & 3 & 3 & 3 & 4 & 4 \\
\hline 6. & $\begin{array}{l}\text { Bekerjasama dan aktif } \\
\text { dalam kelompok }\end{array}$ & 3 & 3 & 3 & 3 & 4 & 3 \\
\hline 7. & $\begin{array}{l}\text { DEMONSTRASI } \\
\text { Mendemonstrasikan hasil } \\
\text { kerja kelompok di depan } \\
\text { kelas }\end{array}$ & 3 & 3 & 3 & 4 & 4 & 4 \\
\hline 8. & $\begin{array}{l}\text { Berpartisipasi aktif dalam } \\
\text { menangapi hasil kerja } \\
\text { kelompok } \\
\text { ditampilkan }\end{array}$ & 2 & 2 & 2 & 4 & 3 & 4 \\
\hline 9. & $\begin{array}{l}\text { ULANGI } \\
\text { Mengulang materi yang } \\
\text { telah dipelajari }\end{array}$ & 2 & 2 & 3 & 4 & 3 & 4 \\
\hline 10. & $\begin{array}{l}\text { Menyelesaikan latihan } \\
\text { yang diberikan peneliti }\end{array}$ & 2 & 4 & 3 & 4 & 4 & 4 \\
\hline 11. & $\begin{array}{l}\text { RAYAKAN } \\
\text { Memberi selamat dengan } \\
\text { cara bertepuk tangan } \\
\text { bersama }\end{array}$ & 3 & 3 & 3 & 4 & 4 & 4 \\
\hline 12. & $\begin{array}{l}\text { Menyelesaikan } \\
\text { pembelajaran dengan rasa } \\
\text { penuh gembira }\end{array}$ & 3 & 3 & 4 & 4 & 4 & 4 \\
\hline JUMLAH SKOR & 32 & 33 & 35 & 42 & 44 & 47 \\
\hline RATA-RATA (DIBAGI 12) & 2,6 & 2,7 & 2,9 & 3,5 & 3,6 & 3,9 \\
\hline PERSENTASE & $66,7 \%$ & $68,8 \%$ & $72,9 \%$ & $87,5 \%$ & $91,7 \%$ & $97,9 \%$ \\
\hline KATEGORI & Baik & Baik & Baik & $\begin{array}{l}\text { Sangat } \\
\text { Baik }\end{array}$ & $\begin{array}{l}\text { Sangat } \\
\text { Baik }\end{array}$ & $\begin{array}{l}\text { Sangat } \\
\text { Baik }\end{array}$ \\
\hline
\end{tabular}

Dari tabel 2 diatas terlihat bahwa secara umum aktivitas siswa di siklus I dan II mengalami peningkatan. Dari jumlah skor, terlihat pertemuan pertama jumlah skor adalah 32, pada pertemuan kedua jumlah skor adalah 33, pada pertemuan ketiga jumlah skor adalah 35, pada pertemuan keenam jumlah skor adalah 42, pada pertemuan ketujuh jumlah skor adalah 44, dan pada pertemuan kedelapan jumlah skor adalah 47. Peningkatan jumlah skor tiap pertemuan adalah dari pertemuan pertama ke pertemuan kedua adalah 1, dari pertemuan kedua ke pertemuan ketiga adalah 2, dari pertemuan ketiga ke pertemuan keenam adalah 7, dari pertemuan keenam ke pertemuan ketujuh adalah 2, dan dari pertemuan ketujuh ke pertemuan kedelapan adalah 5.

Dari rata-rata terlihat pada pertemuan pertama rata-rata adalah 2,6, pada pertemuan kedua adalah 2,7, pada pertemuan ketiga adalah 2,9, pada pertemuan kelima adalah 3,5, pada pertemuan keenam adalah 3,6, dan pada pertemuan ketujuh adalah 3,9. Peningkatan rata - rata tiap pertemuan adalah adari pertemuan pertama ke pertemuan kedua adalah 0,1 , dari pertemuan kedua ke pertemuan ketiga adalah 0,2 , dari pertemuan ketiga ke pertemuan keenam adalah 0,6 , dari pertemuan keenam ke pertemuan ketujuh adalah 0,1 , dan dari pertemuan ketujuh ke pertemuan kedelapan adalah 0,3. 
Sedangkan dari persentase, terlihat pada pertemuan pertama persentase sebesar $66,6 \%$ dengan kategori baik, pada pertemuan kedua sebesar 68,8 \% dengan kategori baik, pada pertemuan ketiga sebesar 72,9 \% dengan kategori baik, pada pertemuan keenam adalah sebesar 87,5 \% dengan kategori sangat baik, pada pertemuan ketujuh persentase sebesar 91,7 \% dengan kategori sangat baik, dan pada pertemuan kedelapan persentase sebesar 97,9\% dengan kategori sangat baik. Peningkatan persentase tiap pertemuan adalah dari pertemuan pertama ke pertemuan kedua sebesar 2,2\%, dari pertemuan kedua ke pertemuan ketiga sebesar 4,1\%, dari pertemuan ketiga ke pertemuan keenam sebesar 14,6\%, dari pertemuan keenam ke pertemuan ketujuh sebesar 4,2\%, dan dari pertemuan ketujuh ke pertemuan kedelapan sebesar 6,2\%. Sedangkan peningkatan kategori tiap siklus adalah pada siklus I dikategorikan baik, sedangkan pada siklus II dikategorikan sangat baik.

Analisis Peningkatan Motivasi Per Siklus

Berdasarkan skor yang diperoleh siswa untuk semua indikator dalam lembar pernyataan angket setelah siklus I dan setelah siklus II yang diperoleh siswa setelah dilaksanakan pembelajaran dengan model pembelajaran Quantum Teaching. Untuk melihat rata-rata analisis peningkatan motivasi yang diadakan setiap setelah pelaksanaan siklus I dan dan siklus II dapat dinyatakan dengan tabel berikut:

Tabel 3

Rata-Rata Analisis Peningkatan Motivasi Belajar Matematika Per Siklus Pada Siswa Kelas V SDN 009 Bangkinang

\begin{tabular}{|c|c|c|c|}
\hline SIKLUS & JUMLAH SKOR & RATA-RATA & KATEGORI \\
\hline Data Awal & 916 & 36,64 & RENDAH \\
\hline Siklus I & 1367 & 54,68 & SEDANG \\
\hline Siklus II & 1894 & 75,76 & TINGGI \\
\hline
\end{tabular}

Dari tabel 3 dapat disimpulkan bahwa hasil motivasi siswa yang berjumlah 25 orang terdapat adanya peningkatan antara jumlah skor dasar, siklus I dan siklus II. Dari jumlah skor terlihat pada hasil penyebaran angket skor dasar sebesar 916, pada hasil penyebaran angket setelah siklus I sebesar 1367 dan pada hasil penyebaran angket setelah siklus II sebesar 1894. Peningkatan jumlah skor setiap penyebaran angket adalah dari skor dasar ke skor setelah siklus I sebesar 451 poin dan dari skor setelah siklus I ke skor setelah siklus II sebesar 527 poin.

Dari rata-rata, terlihat pada skor dasar sebesar 36,64 dengan kategori rendah, setelah siklus I sebesar 54,68 dengan kategori sedang dan setelah siklus II sebesar 75,76 dengan kategori tinggi. Peningkatan rata-rata setiap penyebaran angket adalah dari skor dasar ke skor setelah siklus I sebesar 18,04 poin dan dari skor setelah siklus I ke skor setelah siklus II sebesar 21,08 poin. Peningkatan kategori setiap 
73 Penerapan Model Pembelajaran Quantum Teaching Untuk Meningkatkan Motivasi Belajar Matematika Siswa Kelas V SDN 009 Bangkinang, Putri Hana Pebriana

penyebaran angket adalah pada skor dasar dikategorikan rendah, setelah siklus I dikategorikan sedang dan setelah siklus II dikategorikan tinggi.

\section{SIMPULAN}

Penerapan model pembelajaran Quantum Teaching aktifitas guru dan siswa pada setiap pertemuan mengalami peningkatan. Pada aktifitas guru pertemuan pertama yaitu $68,2 \%$ meningkat ke pertemuan kedua menjadi 70,5\% ( meningkat sebesar 2,3\%),dari pertemuan kedua ke pertemuan ketiga menjadi $72,7 \%$ (meningkat sebesar 2,2 \%), dari pertemuan ketiga ke pertemuan keenam menjadi 88,6\% (meningkat sebesar 15,9\%), dari pertemuan keenam ke pertemuan ketujuh menjadi 93,2\% (meningkat sebesar 4,6\%), dari pertemuan ketujuh ke pertemuan kedelapan 97,7\% (meningkat sebesar 4,5\%). Pada ulangan siklus I nilai rerata siswa meningkat sebesar 9,8 poin dari skor dasar menjadi 73,8. Pada siklus II meningkat sebesar 8,4 poin dari siklus I menjadi 76,95.

Pada hasil angket motivasi siswa setelah siklus I meningkat sebesar 18,04 poin dari skor dasar menjadi 54,68 dengan kategori yang meningkat dari kategori rendah menjadi sedang. Pada siklus II meningkat 21,08 poin dari siklus I menjadi 75,76 dengan kategori yang meningkat dari kategori sedang pada siklus I menjadi kategori tinggi. Dari data tersebut dapat diartikan bahwa penerapan model pembelajaran Quantum Teaching dapat meningkatkan motivasi matematika siswa kelas V SDN 009 Bangkinang.

\section{DAFTAR PUSTAKA}

Arikunto, S dkk. 2009. Penelitian Tindakan Kelas. Jakarta: Bumi Aksara.

KTSP.2007.Kurikulum Tingkat Satuan Pendidikan. Jakarta: Badan Standar Nasional

Mulyasa, E. 2010. Praktik Penelitian Tidakan Kelas. Bandung: Remaja Rosdakarya.

Suherman, E. dan Winataputra, U. 1999. Strategi Belajar Matematika. Jakarta: Universitas Terbuka. 